DOI https://doi.org/10.30525/978-9934-26-114-5-34

\title{
ORGANIZATION OF THE EDUCATIONAL PROCESS AT THE NATIONAL TECHNICAL UNIVERSITY OF UKRAINE «IGOR SIKORSKY KYIV POLYTECHNIC INSTITUTE» DURING COVID-19 QUARANTINE
}

\author{
Gareeva F. M. \\ PhD of Pedagogical sciences, \\ Associate Professor at the Department \\ of General Physics and Physical Processes Modeling \\ National Technical University of Ukraine \\ "Igor Sikorsky Kyiv Polytechnic Institute» \\ Chursanova M. V. \\ PhD of Physical and Mathematical Sciences, \\ Associate Professor at the Department \\ of General Physics and Physical Processes Modeling \\ National Technical University of Ukraine \\ «Igor Sikorsky Kyiv Polytechnic Institute» \\ Kyiv, Ukraine
}

Since the COVID-19 pandemic has broken into our life, it has forced society to bring urgent changes into almost all spheres of public life to keep functioning in the new environment limited by strict quarantine requirements. The higher education system has got a task: to continue high quality training of specialists without interrupting the learning process. To solve this problem, almost all the universities throughout the world have switched to distance learning. And thanks to that it is possible to continue learning online at any part of the world and at any time.

Consider how the National Technical University of Ukraine «Igor Sikorsky Kyiv Polytechnic Institute», one of the Ukraine's oldest universities, has organized educational process during the quarantine period.

To assure the work of all departments, the university-wide «Sikorsky» distance learning platform has been developed [1]. It is an open virtual learning environment of the Igor Sikorsky Kyiv Polytechnic Institute, which provides administrators, teachers and students with ample possibilities for application of modern distance learning technologies, development of web resources for academic disciplines, organization of interactive cooperation between teachers and students, as well as distance learning management. 
The «Sikorsky» platform is based on the specialized web environment Moodle (Modular Object-Oriented Dynamic Learning Environment), G Suite for Education (Google cloud application package for foundation of the information and educational structure of the educational institution) and other software products designed for the distance learning implementation. The main dynamic elements of the platform are: lectures, tests, tasks, glossary and tools for interactive communication in the form of seminars, video conferences, forums, chats and questionnaires. In addition to the web resources contained in Moodle and G Suite for Education, the «Sikorsky» platform allows submission of video courses available to anyone.

Also, there is an Innovative ecosystem «Sikorsky Challenge» acting at the Igor Sikorsky Kyiv Polytechnic Institute, which has been developed to attract creative youth to innovative entrepreneurship [2]. Here technological ideas are grown, innovative start-up companies are launched and developed, and a full technological circle is carried out: starting from the search for new ideas and creating business models and ending with attraction of investments and initiation of new innovative business.

The KPI Scientific and Technical Library («library.kpi.ua») is also taking an active role in supporting educational and research work during quarantine restrictions. Library has expanded the range of services and resources available at distance. In particular, access to more than 70 full-text external scientific databases and electronic archive of educational and scientific materials of the Igor Sikorsky Kyiv Polytechnic Institute has been opened at the «ela.kpi.ua». Electronic delivery of full-text documents from Springer Nature and Wiley information platforms is available at the request of subscribers [3].

An important element of distance education is ensuring of all types of control over mastering of the educational components' materials in the distance mode. This task is performed by the «Electronic Campus» (Ecampus) of the university, which has become an effective tool for implementing the function of administrative control and providing remote evaluation of students' learning during current control, certifications and exams, as well as giving access to lectures, articles, guidelines, etc. [4].

The great part of the work in providing the educational process with distance learning tools and on-line resources is done by the university's departments, where specialized web-platforms are developed. At the Department of General Physics and Physical Processes Modeling of the Igor Sikorsky Kyiv Polytechnic Institute, virtual platforms «physics.kpi.ua» and «physics.zfftt.kpi.ua» have been created and widely used, allowing students to better understand physics, take tests and perform laboratory works with virtual installations [5]. 
The «physics.zfftt.kpi.ua» platform is a dynamic learning environment that fully covers content of the «Physics» discipline curriculum, allowing users to carry out all types of educational activities in distance form.

Protocols of all the laboratory works in electronic form are available on the platform, as well as video records of laboratory experiments implemented by teachers with real equipment located at the university laboratory. That helps students to watch the course of the work for more thoughtful performance of the experiment on their own with virtual simulation of the laboratory setup. The virtual models of laboratory setup are used to reproduce real experimental procedure with help of computer simulation, which at a high level imitates real laboratory research. When performing the work, a student sees schematic view of the setup, observes simulation of the physical phenomenon, receives all the necessary data and parameters for calculations. The platform keeps track of the student's name and group and the date of his virtual experiment [6].

There is access to the electronic library on the platform for more in-depth study of the course, and the e-textbook «PHYSICS. Learn to solve problems. Compensative course» to assist mastering the material of practical classes. Here, for each section of the general physics course, a brief theoretical information is given, examples of problem solving are shown, and tasks for individual work are offered. General recommendations for the stages of problem solving are also given to help students with performing their independent work [7].

A convenient and flexible testing program on the «physics.zfftt.kpi.ua» platform allows students to independently check their skills level, and allows teachers to monitor and evaluate students' knowledge during distance learning. Among the features of the testing system developed on the platform, we should specify possibility to set the start and end dates of testing, the time interval given to a student to pass the test, the possibility to set the number of attempts, to automate calculation of the test results according to the number of points given by the rating system. Test questions are chosen by the program from the «Question Bank», where they are pre-loaded by the teacher, while the questions themselves and the order of answer options fall randomly, which eliminates the possibility of repetition. By creating differrent categories in the "Question Bank», teacher can create tests of different level of complexity and implement individual approach to distance learning. The testing program allows teacher to objectively evaluate students' knowledge and the quality of their mastering of material both on the topic of one lesson and on the whole section of the discipline [7].

With help of the «physics.zfftt.kpi.ua» platform, preparation for the external independent evaluation in physics is carried out, as well as online 
physics training «Physics for international students» for foreign students. The platform is open for development and expansion, and teachers have opportunity to submit their courses in any discipline, give lecture material, create electronic textbooks, compose tests and so on.

An indispensable part in the educational process always belongs to live communication between teacher and students. Such important forms of learning as lectures, seminars and practical classes at the university are held remotely through the use of online communication tools: Zoom, Google Meet, Google Classroom, IDroo and other popular online environments.

Thus, during the quarantine period, distance learning has firmly rooted into the practice of the university education and shows prospects to remain integrated into the educational process in future. After all, this form of education gives advantage in development and realization of modern information technologies in teaching and learning, saving space, electricity and allowing students to study regardless of geography of their location.

\section{References:}

1. Electronic resource: SIKORSKY DISTANCE LEARNING PLATFORM https://www.sikorsky-distance.org/

2. Electronic resource: Innovative ecosystem «Sikorsky Challenge» https://www.sikorskychallenge.com/

3. Robota biblioteky v umovakh karantynu [The work of the library in quarantine] Kyiv Polytechnic. 2020. № 14 (3307), P. 3.

4. Electronic resource: «Electronic campus» https://ecampus.kpi.ua/

5. Electronic resource: platform «physics.kpi.ua» http://physics.zfftt.kpi.ua/

6. Podlasov S.O., Matviychuk O.V. Orhanizatsiya laboratornoho praktykumu z fizyky u tekhnichnomu universyteti na bazi LMS Moodle [Organization of laboratory workshop in physics at the technical university on the basis of LMS Moodle]. The second international scientific-practical conference "Moodle-Moot Ukraine 2014. Theory and practice of using the learning management system Moodle». (Kyiv, KNUBA, May 22-23, 2014): abstracts. 2014. P. 54

7. Podlasov S.O., Matviychuk O.V., Briginets V.P. Orhanizatsiya samostiynoyi roboty studentiv u seredovyshchi LMS Moodle [Organization of independent work of students with the LMS Moodle environment]. Collection of scientific works "Pedagogical sciences». 2016. Vol. 1. № 71 . P. $58-63$ 